\title{
Fiscal Policy Shocks and Private Consumption in Nigeria: Blanchard-Perotti (2002) Approach
}

\author{
OSENI Isiaq Olasunkanmi \\ College of Economics and Management Sciences, University of South Africa (UNISA), South Africa \\ osenibells@ymail.com
}

\begin{abstract}
This paper examines the effects of fiscal policy shocks on private consumption in Nigeria. Albeit, there is a considerable number of works examining the effects of fiscal policy shocks on private consumption globally but in Nigeria, no study has used the structural VAR approach by Blanchard and Perotti (2002) as used in this paper. This approach relies on institutional information about the tax and transfer systems and the timing of tax collection to identify the automatic response of taxes and spending to private consumption as well as to infer fiscal shocks. The key result of this paper is that positive government spending shocks in Nigeria have an instantaneous negative effect on private consumption. The effect becomes significant in the period following the shock. Also, positive tax shocks have a negative effect on private consumption in the period of a shock and the effect becomes statistically insignificant afterwards. On this premises, one-off changes in government spending and taxes in Nigeria are long-lived and short-lived respectively. Thus, the government expenditure changes can be used to support private consumption in the long-run while that of taxes can only be used to support private consumption for a short period.
\end{abstract}

Keywords: Fiscal Policy, Government Spending, Net Taxes, Blanchard-Perotti (2002), Structural Vector Autoregressive

\section{Introduction}

In most studies on fiscal policy around the world especially in Nigeria, the inability to identify the changes in policy variables that are attributable to actual policies rather than to endogenous responses to economic conditions has been a major debatable issues among the policy makers as well as economic scholars. The delay in legislation, the lags in actual implementation of pronounced policies and the time for policy stabilization are also central problems faced in the empirical analysis of fiscal policy realm. To tackle this issue, studies have examined the responses of government spending shocks and tax revenue shocks on private consumers' behaviour in Nigeria (Onodje, 2009; Sousa, 2009; Favero, Giavazzi \& Francesco, 2007; Orisadare, 2012). Apart from the fact that the aforementioned studies have failed to empirically consider the institutional information about the tax and transfer systems as well as the timing of tax collection in their studies, there is no empirical literature in Nigeria that has used the method of Blanchard and Perotti (2002) to examine the relationship between fiscal policy shocks and private consumption. Akins to this, fiscal policy has also been used for several reasons such as raising the output level, protecting the infant industries from unhealthy competition, reduce unemployment by ensuring equitable employment of resources, moderate the rate of inflation, improve balance of payment position, encourage and diversify foreign earning through increased in export activities especially in the non-oil sector in Nigeria before and after independence. However, the emergence of oil boom in 1972 had made the economy to diversify from agricultural proceeds to oil. Thus, the over-reliance on the oil proceeds and neglect of agricultural products have made the economy to suffer deeply from the oil price crises that oil sector has continuously witnessed over the periods in recent time. The adamant of this has resulted in the recent decreased in government revenue in Nigeria. Also, there is a continuous decrease in output level and increase in price of goods and service. To restore the loss in government revenue in Nigeria, government has changed the structure of the tax system and also reviews company tax which may reduce companies' social responsibilities to the community.

This recent development in Nigerian economy has not only affected the growth rate of gross domestic product but also the private consumers. Hence, this study examines the effect of fiscal policy shocks on private consumption in Nigeria using Blanchard-Perotti approach of Structural Vector Autoregressive (SVAR) technique to account for the extent at which the review of the tax structure affects private consumers since 
this method incorporate different tax structure in its methodology which other SVAR techniques do not have. Previous studies that have attempted to address the above issue only used varieties of Vector Autoregressive (VAR) models such as Vector Error Correction Mechanism (VECM), Narrative, Recursive and Sign Restriction Structural VAR (SVAR). In addition, these models only accounted for either dynamic interactions among the variables or unanticipated shocks associated with ordering and sign restriction behaviours. However, these methods neglected the institutional information about the fiscal policy variables (most especially the tax system) and how this information affects macroeconomic variables (private consumption) upon implementation (Ramey, 2011).

Furthermore, studies that have used Blanchard and Perotti (2002) SVAR approach in developed countries noted that the inability to provide full institutional information on the structure of the tax system and government spending was one of the major reasons for slow recovery from the 2001 recession in the U.S. (House and Shapiro, 2006; Yang \& Shu-Chun, 2005). Also, the responses of unanticipated fiscal policy shock from private consumption using Blanchard and Perotti (2002) SVAR approach has not been fully explored among the previous studies most especially in developing countries (House and Shapiro, 2006; Yang \& ShuChun, 2005; and Den-Haan, \& Georg, 2006). In addition, the relationship between fiscal shocks and private consumption in Nigeria using Blanchard and Perrotti (2002) approach of SVAR has not been explored in the literature. Meanwhile, this SVAR approach on like other approaches relies on institutional information about the tax and transfer systems as well as the timing of tax collection to identify the automatic response of taxes and spending to private consumption as well as to infer fiscal shocks (Blanchard \& Perrotti, 2002). Whereas, this approach will enhance the Nigerian policy makers on the timing of tax collection and also provide institutional information to the tax collector in order to boost the means of generating revenue; now that the country is looking for alternative means of raising funds to finance her expenditure while there is fall in the revenue from the country major revenue source i.e. oil proceeds. This paper therefore intends to explore this method by examining the relationship between fiscal policy shocks and private consumption in Nigeria between 1981 and 2014. Following the introductory aspect, section 2.0 contains literature review; section 3.0 entails methodology; section 4.0 presents results and discussion while section 5.0 encompasses conclusion and recommendations.

\section{Literature Review}

Large studies have examined the relationship between fiscal policy shocks and economic activities around the world using different techniques. However, the few studies that have used the method propounded by Blanchard and Perotti (2002) are mainly from developed countries while most studies in Nigeria used other methods of SVAR. Based on this assertion, the following brief literatures are therefore reviewed. Cavallo (2005) investigated the relationship between government employment expenditure and the effects of fiscal policy shocks using VAR technique. The study distinguished between the goods and the employment expenditure components of government consumption in assessing the impact of fiscal shocks on the macro economy. He further identified exogenous fiscal shocks with the onset of military build-ups and showed that these led to a substantial increase in both the number of hours worked and output for the government and showed that allowing for the distinction between the two main components of government consumption improves the quantitative performance of the neoclassical growth model. In doing so, the neoclassical model economy with government employment did a good job of accounting for the dynamic response of private consumption to a fiscal policy shock. While government employment expenditure acted as a transfer payment for households, thereby dampening substantially the wealth effect on consumption and labor supply in association with fiscal shocks.

Heppke-Falk, Tenhofen and Wolf (2006) examined the short-term effects of fiscal policy shocks on the German economy following the SVAR approach by Blanchard and Perotti (2002). They found that direct government expenditure shocks increased output and private consumption on impact with low statistical significance while there was decrease private investment but insignificant. The study also found positive effect between government investment and output and this was equally significant until 12 quarters ahead. Further, the study found not change in the in the sign of the positive consumption response when accounted for anticipated effects of fiscal policy while anticipated expenditure shocks had significant effects on output when shock is realized but not in the period of anticipation. Finally, effects of expenditure shocks were only 
short-lived while tax revenue shocks did not affect output. Kumar et al. (2007) declared that while fiscal consolidations tend to have short-run contractionary effects, it can be expansionary in the long-run. The study also examined the impact of the size of government on growth (where the size of the government is defined as the general government spending in proportion to GDP). They showed that an uncontrolled public spending could negatively affect growth and fiscal imbalances would lead to high levels of taxation and borrowing. As a result, investors will not have any incentive to invest or to innovate. Uncontrolled public spending is an attraction for corrupted bureaucrats and free riders.

Burriel, de Castro, Garrote, Gordo, Paredes and Pérez (2009) examined the effect of fiscal policy shocks among the euro area and US using structural VAR technique based on quarterly dataset of fiscal variables between 1981 and 2007. The study explored the impact of aggregated and disaggregated government expenditure and net tax shocks. In addition, the study included the variables of measuring financial stress (increases in risk) and fiscal stress (sustainability concerns). The result of the study found that GDP and inflation increase in responded to government spending shocks. Meanwhile, government expenditure shocks showed a higher degree of persistence in the US, which appeared to be explained by the persistence of military spending. In turn, net-tax increases the weight on economic activity, with the negative response being shorter-lived in the euro area. Private consumption displayed similar pattern responses to GDP in both the euro area and the US. Private investment responses were not so homogeneous though: it declined in response to higher government spending or net taxes in the US, whereas in the EMU only tax increases appeared to have a negative reaction of private investment. The controlling of stress situations did not change the pattern of impulse responses but affected output multipliers. The financial stress did not significant and in fiscal stress, spending and tax multipliers became higher and more persistent more in the EMU. 1

Shaheen and Turner (2009) characterized the dynamic effect of fiscal policy shock in Pakistan for the period 1973:1-2008:4 by employing a five variable SVAR model and using Blanchard and Perotti (2002) and the Recursive approaches to identify exogenous fiscal shocks. They found that government expenditure increases output in the short run and decreases it in the medium term. Interest rate and inflation increases following government spending shock. Revenue shocks also increase output, inflation and interest rate. While output decreases in the long run as in the case of government spending shock, interest rate increases at a higher level in the medium and long term. They concluded that in Pakistan, increases in government spending and tax can be used to expand output in the short run at the expense of higher output and inflation and SVAR models are rarely used to study fiscal policy in Africa. Abderrahim et al. (2010) studied macroeconomic effects of fiscal shocks in a five variables SVAR mode for Algeria. They found that positive structural shock in government spending has positive effect on output in the short term with very small multiplier. This turns into negative effect in the medium term and in the long run through crowding-out of private investment thereby increasing the average interest rate in the economy. Prices increase persistently following this shock. Public revenue shocks, on the other hand, result in positive impact on government spending in the short term through which the effect on output is channeled i.e., output responds in similar pattern as in the case of government spending shock. The effect on prices and interest rate is persistent and negative in the medium and long term. They used, however, annual data that makes identification of truly exogenous shock rather less reliable.

Mancellari (2011) studied the dynamic effects of change in spending and net revenue on macroeconomic variables in Albania. He used SVAR model and the Blanchard and Perotti identification approach. He estimated multipliers from the model. Accordingly, he found that reduction in tax has the highest impact on output reaching a multiplier of 1.65 after five quarters. Between the two spending components, capital spending has higher role in stimulating the economy than current spending. While interest rate is not responsive for change in any of the spending components, it decreases following a tax cut. Prices; slightly increase following positive shock in current spending, do not respond for a change in capital spending and fall with respect to a cut in taxes. Orisadare (2012) examined the effect of fiscal policy shocks on economic activities in Nigeria from 1970 to 2009 using Recursive SVAR approach. The study found that fiscal policy shock indicated a positive and relatively low significant relationship between government revenue shock and economic activities while a negative significant relationship between government spending shocks and economic activities in Nigeria. Nazir et al. (2013) investigated the long and short run effect of fiscal policy on GDP growth of Pakistan. Government consumption expenditure and per capita real revenues are used as 
fiscal variables while discount rate, trade openness and gross fixed capital formation are treated as control variables to analyze their impact on GDP growth for the economy of Pakistan for the period of 1980-2012. Johansen co-integration and vector error correction model are applied to know the effects of fiscal variables on GDP growth in short and long run. The findings show that fiscal policy has vital role for meaningful economic progress. This study pointed out that government consumption expenditure has negative relation with GDP growth and public revenues have a progressive impact on economic activity of Pakistan. Less consumption expenditure and effective revenue structure is advocated to boost the economic growth of Pakistan. In summary, only few of the studies reviewed that used Structural VAR technique propounded by Blanchard and Perotti (2002) are either from developed nations or developing nations excluding Nigeria. In Nigeria, this study therefore fills this gap by using Blanchard and Perotti (2002) approach of SVAR to examining the relationship between fiscal policy shocks and private consumption.

\section{Methodology}

In order to estimate the empirical relationship between fiscal policy shock and private consumption in Nigeria, the paper employed Blanchard and Perotti (2002) SVAR model. Thus, the paper considered the reduced form of VAR model that has 5 variables embedded in vector matrix $\left(X_{t}\right)$ that consists of two policy variables (government expenditure $\left(g \exp _{t}\right)$ and tax revenue $\left(t r_{t}\right)$ ) and three non-policy variables (private consumption $\left(p c_{t}\right)$, government debt $\left(b_{t}\right)$ and interest rate $\left.\left(i r_{t}\right)\right)$ as follows:

$X_{t}=\Psi(L) X_{t-1}+U_{t}$

Where $X_{t}=\left[\begin{array}{lllll}g \exp _{t} & t r_{t} & p c_{t} & b_{t} & i r_{t}\end{array}\right]^{\prime}$ and all the variables are in log-transformed. $\Psi(L)$ is an autoregressive lag polynomial and $\left(U_{t}=\left[u_{t}^{g \exp } u_{t}^{t r} u_{t}^{p c} u_{t}^{b} u_{t}^{i r}\right]\right)$ is the vector of reduced form errors. Since this paper used quarterly data, as a result, a lag length of four is supposed to be chosen as suggested by various lag length identifiers ranging from the Akaike information criterion (AIC) to Hannan-Quinn information criterion.

However, incorporate column matrices $\boldsymbol{X}$ and $\boldsymbol{U}$ in equation 1, the model can therefore be written in conventional form as follows:

$$
\left[\begin{array}{c}
g \exp _{t} \\
t r_{t} \\
p c_{t} \\
b_{t} \\
i r_{t}
\end{array}\right]=\psi(L)\left[\begin{array}{c}
g \exp _{t-1} \\
t r_{t-1} \\
p c_{t-1} \\
b_{t-1} \\
i r_{t-1}
\end{array}\right]+\left[\begin{array}{c}
u^{g \exp } \\
u^{t r} \\
u^{p c} \\
u^{b} \\
u^{i r}
\end{array}\right]
$$

Following the work of Blanchard and Perotti (2002), equation 2 above can be expressed in matrices A and B. From these matrices, the coefficients needed to construct their estimates in order to compute the impulse responses to fiscal shocks can be expressed as follows:

$A_{t} U_{t}=B e_{t}$

Such that $U_{t}=A^{-1} B e_{t}$

$e_{t}=\left\{\begin{array}{lll}\text { Vector of } & \text { Structural policy shocks }\left(e_{t}^{g \text { exp }}, e_{t}^{t r}\right) ; & \text { and } \\ \text { non-policy } & \text { shocks }\left(e_{t}^{p c}, e_{t}^{b}, e_{t}^{i r}\right) . & \end{array}\right\}$

Thus, matrices $\mathrm{A}$ and $\mathrm{B}$ are as follows: 


$$
\left[\begin{array}{ccccc}
1 & 0 & -\alpha_{p c}^{g \exp } & -\alpha_{b}^{g \exp } & -\alpha_{i r}^{g \exp } \\
0 & 1 & -\alpha_{p c}^{t r} & -\alpha_{b}^{t r} & -\alpha_{i r}^{t r} \\
-\alpha_{31} & -\alpha_{32} & 1 & 0 & 0 \\
-\alpha_{41} & -\alpha_{42} & -\alpha_{43} & 1 & 0 \\
-\alpha_{51} & -\alpha_{52} & -\alpha_{53} & -\alpha_{54} & 1
\end{array}\right]\left[\begin{array}{c}
u_{t}^{g \exp } \\
u_{t}^{t r} \\
u_{t}^{p c} \\
u_{t}^{b} \\
u_{t}^{i r}
\end{array}\right]=\left[\begin{array}{ccccc}
b_{11} & b_{12} & 0 & 0 & 0 \\
b_{21} & b_{22} & 0 & 0 & 0 \\
0 & 0 & b_{33} & 0 & 0 \\
0 & 0 & 0 & b_{44} & 0 \\
0 & 0 & 0 & 0 & b_{55}
\end{array}\right]\left[\begin{array}{c}
e_{t}^{g \exp } \\
e_{t}^{t r} \\
e_{t}^{p c} \\
e_{t}^{b} \\
e_{t}^{i r}
\end{array}\right]
$$

To justify the system, the paper used $2 k^{2}-\frac{k(k+1)}{2}$ ( $k$ is the number of endogenous variables) to impose constraints on both matrices i.e. 35 constraints. Hence, there are 18 constraints in matrix B while the leading diagonal of matrix A has 5 restrictions. All the constraints in matrix B are zero (0). The restrictions imposed on the matrices are obtained based on the structure of the Nigerian economy. These are further calculated using exogenous elasticities as presented in tables 1 and 2 below. Following the work of Lozano and Rodriquez (2008), and Ravnik and Zilic (2011), the exogenous elasticities of government revenue to private consumption and government debt are obtained by estimating equations 5 and 6 with Ordinary Least Square (OLS) techniques respectively using available data from Nigeria such as Oil Revenue, Non-Oil Revenue and Excise duty, income taxes and social contributions (such as grants, stabilization receipt and others) which are mainly obtained from Central Bank statistical bulletin, 2014. The private consumption elasticity of government revenues is calculated using the following formula:

$\alpha_{p c}^{t r}=\sum_{i=1}^{n} \varepsilon_{t b_{i}}^{t r_{i}} \times \varepsilon_{p c}^{t b_{i}} \times \frac{W_{i}}{W}$

where $\varepsilon_{t b_{i}}^{t r_{i}}$ is the elasticity of each tax category to its tax base, $\varepsilon_{p c}^{t b_{i}}$ is the elasticity of each tax base to GDP, while $\frac{W_{i}}{W}$ is the weight of type $i$ tax in the sum of taxes, $W=\sum_{i=1}^{n} W_{i}$. Similarly, the equation (6) is used to calculate the required elasticity of government revenue to government debt using the same categories of tax revenue and tax base as shown below:

$\alpha_{b}^{t r}=\sum_{i=1}^{n} \varepsilon_{t b_{i}}^{t t_{i}} \times \varepsilon_{b}^{t b_{i}} \times \frac{W_{i}}{W}$

where $\varepsilon_{t b_{i}}^{t t_{i}}$ is the elasticity of each tax category to its tax base, $\varepsilon_{b}^{t b_{i}}$ is the elasticity of each tax base to GDP. The corresponding results of the elasticity generated are presented in table 1 and 2 below.

Table 1: Construction of Elasticity of Government Revenue to Private Consumption

\begin{tabular}{lccccc}
\hline Revenue & $\varepsilon_{t b_{i}}^{t r_{i}}$ & $\varepsilon_{p c}^{t b_{i}}$ & $\varepsilon_{p c}^{t r}=\varepsilon_{t b_{i}}^{t r_{i}} \times \varepsilon_{p c}^{t b_{i}}$ & $\frac{W_{i}}{W}$ & $\varepsilon_{t b_{i}}^{t t_{i}} \times \varepsilon_{p c}^{t b_{i}} \times \frac{W_{i}}{W}$ \\
\hline Oil Revenue & 0.94 & 0.99 & 0.93 & 0.99 & 0.92 \\
Non-Oil Revenue & 1.01 & 0.99 & 0.99 & 0.26 & 0.25 \\
Income Tax & 0.76 & 0.50 & 0.38 & 0.06 & 0.02 \\
Excise Duty & 1.34 & 1.01 & 1.35 & 0.09 & 0.12 \\
Social Contribution & 0.43 & 0.89 & 0.38 & 0.09 & 0.04 \\
$\alpha_{p c}^{t r}=\sum_{i=1}^{n} \varepsilon_{t b_{i}}^{t r_{i}} \times \varepsilon_{p c}^{t b_{i}} \times \frac{W_{i}}{W}=1.35$ & & & &
\end{tabular}

Source: Author, 2015 
Table 2: Construction of Elasticity of Government Revenue to Government Debt

\begin{tabular}{lccccc}
\hline Revenue & $\varepsilon_{t b_{i}}^{t r_{i}}$ & $\varepsilon_{b}^{t b_{i}}$ & $\varepsilon_{b}^{t r}=\varepsilon_{t b_{i}}^{t r_{i}} \times \varepsilon_{b}^{t b_{i}}$ & $\frac{W_{i}}{W}$ & $\varepsilon_{t b_{i}}^{t r_{i}} \times \varepsilon_{b}^{t b_{i}} \times \frac{W_{i}}{W}$ \\
\hline Oil Revenue & 0.94 & 0.70 & 0.66 & 0.99 & 0.65 \\
Non-Oil Revenue & 1.01 & 0.70 & 0.71 & 0.26 & 0.18 \\
Income Tax & 0.76 & 0.52 & 0.40 & 0.06 & 0.02 \\
Excise Duty & 1.34 & 0.69 & 0.92 & 0.09 & 0.08 \\
Social Contribution & 0.43 & 0.52 & 0.22 & 0.092 \\
$\alpha_{b}^{t r}=\sum_{i=1}^{n} \varepsilon_{t b_{i}}^{t r_{i}} \times \varepsilon_{b}^{t b_{i}} \times \frac{W_{i}}{W}=0.95$ & & & &
\end{tabular}

Source: Author, 2015

However, the impact of reduced innovation of private consumption on reduced innovations of tax revenue is 1.35 (that is, exogenous elasticity 1.35) and impact of reduced innovation of government debt on reduced innovations of taxes is 0.95 (that is, exogenous elasticity 0.95 ) using exogenous elasticity in line with the works of Caldara and Kamps (2008) and Ravnik and Zilic (2011). Therefore, by incorporating the values of the calculated elasticities and all the assumptions stated earlier into the SVAR matrices A and B described above, the estimated matrices $\mathrm{A}$ and $\mathrm{B}$ becomes:

$\left[\begin{array}{ccccc}1 & 0 & 0 & 0.5 & 0 \\ 0 & 1 & -1.35 & -0.95 & 0 \\ -\alpha_{31} & -\alpha_{32} & 1 & 0 & 0 \\ -\alpha_{41} & -\alpha_{42} & -\alpha_{43} & 1 & 0 \\ -\alpha_{51} & -\alpha_{52} & -\alpha_{53} & -\alpha_{54} & 1\end{array}\right]\left[\begin{array}{c}u_{t}^{g \exp } \\ u_{t}^{t r} \\ u_{t}^{p c} \\ u_{t}^{b} \\ u_{t}^{i r}\end{array}\right]=\left[\begin{array}{ccccc}b_{11} & b_{12} & 0 & 0 & 0 \\ b_{21} & b_{22} & 0 & 0 & 0 \\ 0 & 0 & b_{33} & 0 & 0 \\ 0 & 0 & 0 & b_{44} & 0 \\ 0 & 0 & 0 & 0 & b_{55}\end{array}\right]\left[\begin{array}{c}e_{t}^{g \exp } \\ e_{t}^{t r} \\ e_{t}^{p c} \\ e_{t}^{b} \\ e_{t}^{i r}\end{array}\right]$

Thus, the estimated elements in matrix A are nine (9) while the estimated elements in matrix B are seven (7). In total, there are sixteen elements to be estimated from matrices A and B.

Scope, Data Sources and Measurement: The study examined the relationship between fiscal policy shocks and private consumption in Nigeria between 1981:1 and 2014: 4 and this covered a period of 34 years and 4 quarters which sum-up to 136 observations. The study used a quarterly secondary data on private consumption (final household consumption expenditure), government expenditure (total current expenditures of the public sector less net investment to which we subtract net interest payments), government revenue (total current receipt of the public sector), government debt (total sum of holdings federal government's domestic debt outstanding and the total Nigeria's external debt outstanding in billions of naira) and interest rate (minimum rediscount rate) from 1981:1 to 2014:4 and the data were sourced from World development Indicator (WDI), World Bank database, 2015 and Central Bank Statistical bulletin, 2014.

\section{Results and Discussion}

Time Series Properties of the Variables Employed: Testing for non-stationarity in the form of unit roots has become a clip of time series econometrics (Engle and Granger, 1987). The reason for this stalk from the challenges that non-stationary data confront for inference using standard statistical techniques such as Ordinary Least Square Method (OLS). It is well established, for instance, that OLS produces spurious results when applied to data with unit roots. What OLS is really estimating in such situations are common trends and not the underlying relationships between two or more variables. Inadequately accounting for unit roots can lead to estimates that appear to be significant and meaningful but in reality are meaningless and insignificant (Hamilton, 1994). If data are non-stationary, transformations such as differencing are often employed to induce stationarity. While differencing a data series, is common in ARIMA modeling, it is less common in VARs and is usually discouraged because such transformations discard long-run information. On the other 
hand, if testing reveals the likely presence of unit roots and the absence of error correction, then the standard statistical tests used for conducting Granger tests will still be valid when applied to differenced data (Brandt and Williams, 2007). Therefore, this study employs Augmented Dickey Fuller (ADF) of unit root test with Constant, without trend and Constant, Linear Trend using automatic lag length selection based on Akaike Information Criterion (AIC) and Schwarz Information Criterion (SIC). The results of the unit roots are presented in table 3.

Table 3: Unit Root Test using Augmented Dickey Fuller (ADF) Technique

\begin{tabular}{|c|c|c|c|c|c|c|c|}
\hline \multirow[b]{2}{*}{ Variables } & \multirow{2}{*}{$\begin{array}{l}\text { Level } \\
\text { Constant }\end{array}$} & \multirow[b]{2}{*}{$\begin{array}{l}\text { Constant, } \\
\text { Trend }\end{array}$} & \multirow[b]{2}{*}{ Linear } & \multicolumn{2}{|c|}{ First Difference } & \multirow[b]{2}{*}{$\begin{array}{l}\text { Order } \\
\text { Integration }\end{array}$} & \\
\hline & & & & Constant & $\begin{array}{l}\text { Constant, } \\
\text { Linear Trend }\end{array}$ & & of \\
\hline $\ln P C$ & -0.7821 & -1.1029 & & $-4.5665^{*}$ & $-4.5995^{*}$ & $\mathrm{I}(1)$ & \\
\hline $\ln B$ & -1.9877 & -1.7138 & & $-4.1899^{*}$ & $-4.4055^{*}$ & I(1) & \\
\hline InGEXP & -1.3317 & -0.7381 & & $-7.2304^{*}$ & $-4.3478^{*}$ & I(1) & \\
\hline IR & -2.9006 & -2.8509 & & $-6.0496 *$ & $-6.1677^{*}$ & I(1) & \\
\hline $\operatorname{lnTR}$ & -0.4402 & -2.6686 & & $-6.2488^{*}$ & $-4.7880^{*}$ & I(1) & \\
\hline \multicolumn{8}{|l|}{ Critical } \\
\hline \multicolumn{8}{|l|}{ Values: $1 \%$} \\
\hline $5 \%$ & -3.6793 & -4.2967 & & -3.6793 & -4.3098 & & \\
\hline \multirow[t]{2}{*}{$10 \%$} & -2.9678 & -3.5684 & & -2.9678 & -3.5742 & & \\
\hline & -2.6230 & -3.2184 & & -2.6230 & -3.2217 & & \\
\hline
\end{tabular}

Note: ${ }^{* * *}$ ) implies $1 \%(5 \%)$ significance level.

Source: Author, 2015

The results in table 3 showed that all the variables were non-stationary at level without a trend term. However, the results of the unit root test with a trend term indicated that all the variables were stationary at first difference and non-stationary at $5 \%$ level; that is I(0). Thus, the study concluded that all the variables were integral order of one, I (1) series by considering a unit root test with a constant, linear trend.

Co-integration Test and Vector Error Correction Model: Having established the order of integration of our series, the study determined the number of long-run equilibrium relationships or Co-integrating vectors between the variables. Since the variables are found to be integrated of the same order, such as I(1) as shown above using Augmented Dickey-Fuller test results, it implies that an equilibrium relationship exists among the variables. Therefore, since the main focus of the study is to examine the effect of fiscal policy shocks on private consumption in Nigeria, we conduct a Co-integration test in line with Johansen test taking into consideration all the variables that were integrated of order one I(1) using the decision of ADF.

Table 4: Johansen Maximum likelihood test for Co-integration (PC, B, GEXP, IR, TR)

\begin{tabular}{|c|c|c|c|c|c|c|}
\hline Hypotheses & Trace Test & $\begin{array}{l}5 \% \\
\text { values }\end{array}$ & Critical & $\begin{array}{l}\text { Max-Eigen } \\
\text { Statistic }\end{array}$ & $\begin{array}{l}5 \% \\
\text { values }\end{array}$ & Critical \\
\hline $\mathrm{R}=0$ & 477.75 & 159.53 & & 192.42 & 52.36 & \\
\hline$R \leq 1$ & 285.33 & 125.62 & & 107.16 & 46.23 & \\
\hline $\mathrm{R} \leq 2$ & 178.17 & 95.75 & & 60.11 & 40.08 & \\
\hline$R \leq 3$ & 28.40 & 29.80 & & 17.71 & 21.13 & \\
\hline $\mathrm{R} \leq 4$ & 10.69 & 15.49 & & 10.67 & 14.26 & \\
\hline $\mathrm{R} \leq 5$ & 0.02 & 3.48 & & 0.02 & 3.84 & \\
\hline
\end{tabular}

Source: Author, 2015

Thus, the result of the co-integration test revealed that there were three co-integrating vectors based on Trace statistic and Eigen values since the hypotheses of no co-integration were rejected at $5 \%$ level for both test using Mackinnon-Haug Michelis (1999) p-values as shown in table 4. In addition, after establishing the long-run relationship among the variables, the study investigated the short-run dynamics of the model using Error Correction Mechanism (ECM). This shows the speed of convergence towards equilibrium among the variables. The empirical result in table 5 was analyzed with the use of the two-step Engle and Granger (1987) 
model which suggests that any set of Co-integrated time series has an error-correction representation, which reflects the short-run adjustment mechanism. The motive of the analysis is to discover whether the short-run dynamics are influenced by the estimated long-run equilibrium condition that is, the Co-integrating vectors. A crucial parameter in the estimation of the short-run dynamic model is the coefficient of the error-correction term which measures the speed of adjustment between fiscal policy shocks and private consumption in Nigeria to equilibrium level.

Table 5: Error Correction Mechanism Results

\begin{tabular}{llll}
\hline Variables & Coefficients & Standard Error & t-Statistic \\
\hline ECM(-1) & -0.67 & 0.31 & $-2.17^{* *}$ \\
$\Delta \ln P C(-1)$ & 0.40 & 0.15 & $2.63^{* *}$ \\
$\Delta \mathrm{IR}$ & 0.47 & 0.70 & 0.67 \\
$\Delta \operatorname{lnGEXP}$ & -0.07 & 0.03 & $-2.47^{* *}$ \\
$\Delta \ln B$ & 0.57 & 0.20 & $2.93^{*}$ \\
Adjusted R-square: & 0.66 & & \\
Durbin-Watson stat: & 1.95 & & \\
F-statistic: & 10.09 & & \\
\hline
\end{tabular}

Note: $\left.{ }^{* * *}\right)^{* * *}$ implies $1 \%(5 \%) 10 \%$ significance level. $\mathbf{\Delta P C}$ is the dependent variable

Source: Author, 2015

The results show that the parameter of the error-correction terms in the model is statistically significant and correctly signed. This confirmed that the relationship between fiscal policy shocks and private consumption in Nigeria has automatic adjustment mechanism and the economy responds to deviations from equilibrium in a balancing manner. The value of -0.67 for the coefficient of error correction term suggested that the fiscal policy shocks and private consumption will converge towards its long-run equilibrium level in a moderate speed after the fluctuation in fiscal policy shocks and private consumption. Eliminating for instance, 95\% of a fluctuation in fiscal policy shock variables and private consumption would take a little more than 8 years or precisely 32.16 quarters to converge to long-run equilibrium level.

Results of Structural Break Test: Since the study used quarterly data, the study therefore test for structural breaks in line with the work of Brown et al. (1975) that proposed two tests Cumulative Sum and cumulative Sum of Square to check the structural stability of the data used for analysis. Thus, CUSUM test captured the systematic changes in regression coefficients while CUSUMSQ detained the departure of parameters from constancy.

Figure 1: Cumulative Sum of Recursive Residual

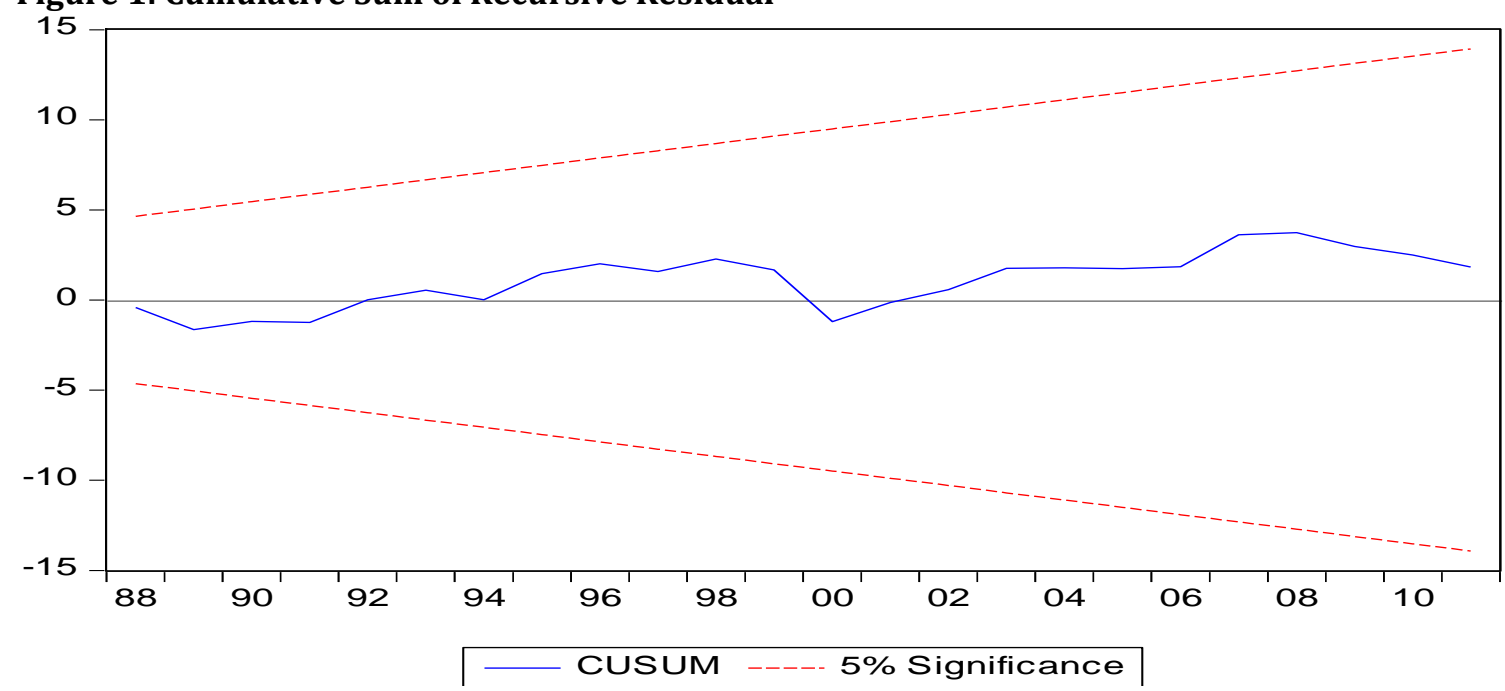

Source: Author, 2015 


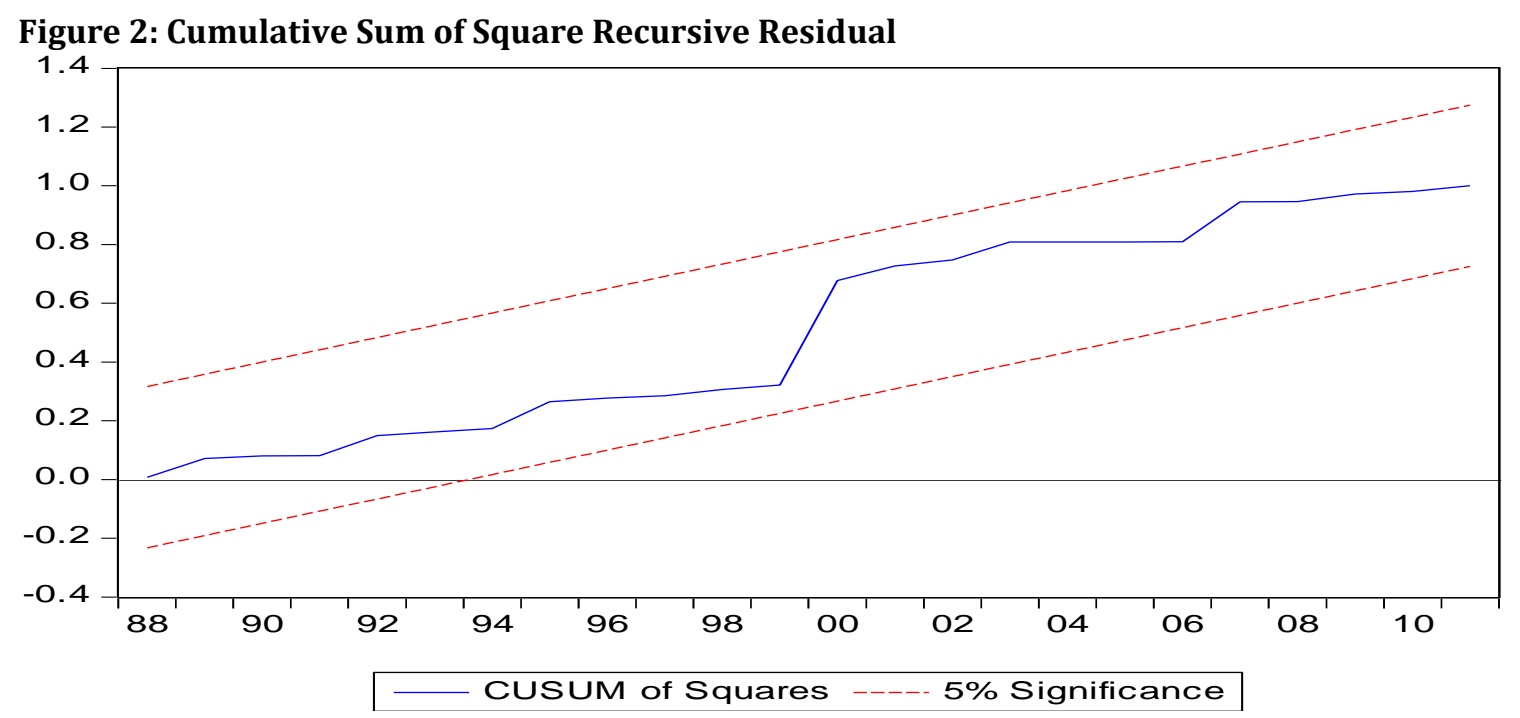

Source: Author, 2015

Hence the CUSUM test results indicated that there is no break since the straight line is within the $5 \%$ critical band of the CUSUM test while the result of the CUSUMSQ test revealed that the detain of the departure of the parameters from the constancy is within the straight line that represents critical bond at $5 \%$ significant level as shown in figures 1 and 2 above.

Estimation of Lag Length of the SVAR Model: To avoid spurious results in the SVAR model is by adding a sufficient number of autoregressive lags. Therefore, the process of determining the number of lagged values needed to be included in the SVAR model is an integral part of specifying a stable SVAR model. However, incorrect specification of the lag length of a SVAR model can lead to inconsistent impulse responses and variance decompositions (Braun \& Mittink, 1993). Also, over-fitting the model may result to inefficiency while under-fitting may cause some dynamics in the system to be unrealized. Several methods and tests were used to identify the true lag length of the unrestricted VAR model with constant and trend. Therefore, the paper used various lag length identifiers such as Akaike information criterion (AIC), Schwarz's information criterion (SIC) and so on from VAR system to identify the appropriate lag length. The results of the lag length selection are shown in the table 3 with orders of $m=1, \ldots, 8$ with constant and linear deterministic terms.

Table 6: Estimated Results of VAR Lag Length Selection Criteria

\begin{tabular}{lllllll}
\hline Lag & LogL & LR & FPE & AIC & SIC & HQ \\
\hline 0 & 509.8923 & NA & $1.14 \mathrm{e}-10$ & -8.705039 & -8.586350 & -8.656858 \\
1 & 1088.988 & 1098.285 & $8.10 \mathrm{e}-15$ & -18.25842 & -17.54628 & -17.96933 \\
2 & 1159.107 & 126.9385 & $3.73 \mathrm{e}-15$ & -19.03632 & $-17.73074^{*}$ & -18.50633 \\
3 & 1170.266 & 19.24074 & $4.76 \mathrm{e}-15$ & -18.79769 & -16.89867 & -18.02680 \\
4 & 1219.006 & 79.83193 & $3.20 \mathrm{e}-15$ & -19.20699 & -16.71452 & -18.19519 \\
5 & 1303.488 & 131.0925 & $1.17 \mathrm{e}-15$ & -20.23254 & -17.14662 & $-18.97984^{*}$ \\
6 & 1338.106 & $50.73469^{*}$ & $1.02 \mathrm{e}-15^{*}$ & $-20.39839^{*}$ & -16.71902 & -18.90478 \\
7 & 1345.707 & 10.48367 & $1.43 \mathrm{e}-15$ & -20.09840 & -15.82559 & -18.36388 \\
8 & 1356.985 & 14.58385 & $1.91 \mathrm{e}-15$ & -19.86182 & -14.99556 & -17.88639 \\
* indicates lag order selected by the criterion & & & \\
\multicolumn{7}{l}{ LR: sequential modified LR test statistic (each test at 5\% level) } \\
FPE: Final prediction error
\end{tabular}

Source: Author, 2015 
The information criterion presented in table 6 offers mixed results. Based on LR, FPE, AIS, HQ indicating the choice of 6-lag, whereas the SIC suggests an order of 2-lag length. Thus, this result showed that four out of five criteria indicated an optimal lag order 6 , while only SIC supported an order of 2 . To test the validity of the result, a lag exclusion Wald test was conducted to verify whether six lags was suitable for the unrestricted VAR model or not.

Table 7: VAR Lag Exclusion Wald Test

\begin{tabular}{lllllll}
\hline & GEXP & TR & PC & B & IR & Joint \\
\hline Lag 1 & 35.53214 & 115.2057 & 21.19538 & 125.0730 & 307.3088 & 852.1816 \\
& {$[1.18 \mathrm{e}-06]$} & {$[0.000000]$} & {$[0.000744]$} & {$[0.000000]$} & {$[0.000000]$} & {$[0.000000]^{*}$} \\
Lag 2 & 24.31813 & 34.58084 & 37.41361 & 15.43155 & 44.89521 & 158.4691 \\
& {$[0.000189]$} & {$[1.82 \mathrm{e}-06]$} & {$[4.95 \mathrm{e}-07]$} & {$[0.008669]$} & {$[1.52 \mathrm{e}-08]$} & {$[0.000000]^{*}$} \\
\hline
\end{tabular}

Note: Numbers in [ ] are p-values. * indicates statistical significant at $5 \%$ level

Source: Author, 2015

The results of the $X^{2}$ statistic in table 7 above for the joint significance of all endogenous variables in the VAR at two lag lengths was jointly significant at the $5 \%$ level of significance, indicating that 2-lag lengths is the optimal. Thus this paper used 2-lag lengths for the analysis of the fiscal policy shocks.

Discussion of the Results of the Effect of Fiscal Policy Shocks on Private Consumption: Using the Structural Vector Autoregressive (SVAR) approach proposed by Blanchard and Perotti (2002) and Perotti (2004) to examine the impact of fiscal policy shocks on private consumption, the paper arranged the variables in the following order- government expenditure, tax revenue, private consumption government debt and interest rate. Thus, this ordering is based on the following assumptions and justifications: (a) government spending was placed first because it does not react contemporaneously to shocks to other variables in the system and was not affected by business cycle fluctuation; (b) tax revenue was ordered second, which implied that it does not react contemporaneously to private consumption, tax revenue and interest rate shocks but was affected by government spending shocks; (c) private consumption was ordered third meaning that it was contemporaneously affected by government spending, government debt and tax revenue shocks; (d) Government debt was ordered as fourth, meaning that it was not affected contemporaneously by private consumption and interest rate shocks but it reacted to government spending shocks; (e) interest rate was placed last, because it was affected by all shocks from the system since interest are not payable on fiscal variables and therefore not sensitive to interest rate changes. This could be taken as the justification for the placement of the interest rate among the variables. This method was also used by Caldara and Kamps (2008), Ravnik and Žilić (2011) who investigated fiscal policy shocks for Croatia. The basic point in this approach was that identification of fiscal policy shocks was achieved by exploiting decision lags in policy making and information about the elasticity of fiscal variables to private consumption.

Empirical Analysis of Fiscal Policy Shocks - Blanchard and Perotti (2002) Approach: The SVAR results of fiscal policy shocks on private consumption in line with Blanchard and Perotti (2002) approach was presented in table 8.

Table 8: Empirical Analysis of Fiscal Policy Shocks - Blanchard and Perotti (2002) Approach

\begin{tabular}{lllllllllll}
\hline & $\boldsymbol{\beta}_{\boldsymbol{p c}, \boldsymbol{i r}}$ & $\boldsymbol{\beta}_{\boldsymbol{p c}, \boldsymbol{B}}$ & $\boldsymbol{\beta}_{\boldsymbol{p c}, \boldsymbol{t r}}$ & $\boldsymbol{\beta}_{\boldsymbol{p c}, \boldsymbol{g e x p}}$ & $\boldsymbol{\beta}_{\boldsymbol{g e x p}, \boldsymbol{i r}}$ & $\boldsymbol{\beta}_{\boldsymbol{g e x p}, \boldsymbol{B}}$ & $\boldsymbol{\beta}_{\boldsymbol{g e x p}, \boldsymbol{t r}}$ & $\boldsymbol{\beta}_{\boldsymbol{t r}, \boldsymbol{i r}}$ & $\boldsymbol{\beta}_{\boldsymbol{t r}, \boldsymbol{B}}$ & $\boldsymbol{\beta}_{\boldsymbol{B}, \boldsymbol{i r}}$ \\
\hline Coefficients & $-0.73^{*}$ & 0.38 & $-0.97^{*}$ & $-0.36^{*}$ & $-0.98^{*}$ & 0.19 & 0.07 & -0.63 & 0.59 & $-0.67^{*}$ \\
z-value & -2.85 & 1.16 & -13.99 & -3.20 & -2.54 & 0.35 & 0.63 & -1.03 & 0.67 & -16.98 \\
\hline
\end{tabular}

Note: $* * *$ *** implies $1 \%$ (5\%) $10 \%$ significance level.

Source: Author, 2015

The estimated result showed that the estimated coefficient of government debt shock to private consumption was positively signed but statistically non-significant. It suggested that a positive one percent shock in government debt increased the private consumption by 38 percent. This finding supported the Keynesian proposition that says an expansionary fiscal policy through government debt would enhance income and aggregate demand and thus foster private consumption. This was in conformity with the study conducted by 
Ravnik and Žilić (2011) on Croatia's economy. The coefficient of government spending shocks was negatively signed and statistically significance at 1 percent level. Thus, a shock in government spending hit private consumption negatively in Nigeria. This showed that a negative one percent shock in government expenditure decreased private consumption by 36 percent. Hence, the result indicated that government spending shock crowded-in private consumption in Nigeria. This finding was in conformity with nonKeynesian proposition which states that an expansionary fiscal policy in terms of increase in government expenditure would result to a contractionary effect on private consumption. This result supports the view of Giavazzi and Pagano (1996), Giavazzi, Jappelli and Pagano (2000) and Onodje, (2009).

The negative coefficient of $\beta_{p c, t r}$ showed that a negative shock in tax revenue contributed to a change in private consumption and statistically significant. This showed that a unit negative shock in government revenue would reduce private consumption by 97 percent and hence, crowded-in private consumption. This might arise as a result of increase in tax revenue through increase in tax rate by the government in order to finance her excess spending or to pay back the debt incurred through increase in government expenditure on infrastructural facilities; such as provision of tidy road, hospitals and building of more schools as well as increase in transfer payment like bursary, pension and so on. A positive and non-significant value of $\beta_{\text {gexp, } B}$ indicated that increase in government debt would lead to increase in government expenditure. The negative and statistically significant value of $\beta_{p c, i r}$ showed that decrease in interest rates would increase aggregate demand and thus, private consumption. A negative one percent shock in interest rates thus increased private consumption by 0.73 percent. This was in conformity with the result of Perotti (2008). A negative value of $\beta_{B, i r}$ suggested an inverse relationship between lending rate and government debt. This relationship was statistically significant and showed that a positive shock in interest rate contributed to decrease in lending rate and this would foster aggregate demand and private consumption in the country. Hence, as interest rates charges on debt reduce, government intends to borrow more at highly reduced interest rates in order to enhance aggregate demand and private consumption. A positive value of $\beta_{t r, B}$ implies that an increase in government debt would result in an increase in government revenue and this estimate was theoretically consistent. The estimated coefficient of $\beta_{\text {gexp,tr }}$ suggested a direct relationship between tax revenue shocks and government expenditure. Thus, since tax revenue was an income to the government, it would enhance both private and public consumption. This was in conformity with the result of Alfred et al. (2013).

Variance Decomposition of Fiscal Policy Shocks: The decomposition of forecast variance was used to examine how much the fitted SVAR deviates from the actual values of the vector of endogenous variables. What percentage of a variable's deviation from its forecasted value was attributable to another variable provided additional insight into historical relationships. Evidence for contemporaneous correlation exists when one variable begins to explain the forecast variance in the other with a time lag. This occurs because the correlation takes time to work through the lags in the system. Table 6 to 9 reported the results of the forecast error variance decomposition for the SVAR model of the relationship between fiscal policy variables shocks (government expenditure, tax revenue and government debt) and private consumption in Nigeria. When interpreting the results, the ordering of the variables was important because the decomposition assumed that all the variances in the initial period were entirely due to the first variable in the ordering. As the forecast horizon expanded, the other variables in the system began to exert their influence. In Table 9, for example, if interest rates variable was first in the ordering, this means that it explained all of its forecast variance in the initial period. It was possible that results might be sensitive to potentially arbitrary variable orderings. Without strong theoretical guidance, a common recommendation was to switch the variable orderings in order to check for robustness.

The first column in Table 9 listed the steps in the forecast with each step corresponding to one quarter. Thus, the first step represented the first quarter of the forecast while the tenth step represented the tenth lag. The total forecast horizon covered one hundred and thirty-two quarters (thirty-three years). The next four columns in the table reported the percentage of forecast variance in the government debt explained by government debt, tax revenue, government expenditure and private consumption, respectively. The response of government debt to shocks in tax revenue was zero in the first period and negative in the second period. These shocks continued to increase till the fifth period and decrease in the sixth period. The shocks continued to be volatile from the sixth periods to the tenth period. The response of government debt to shocks in government expenditure also recorded zero in the first period and continued to be volatile till the ninth years 
and negative in the tenth year. The negative shock that emanated from government expenditure to government debt indicated that discretionary government policy in terms of change in government expenditure reacted inversely to change in government debt. Furthermore, the response of government debt to shocks in private consumption was negative for all the periods except the ninth and tenth period. Thus, this indicated that changed in government debt in Nigeria responded to negative shocks from private consumption. Hence, increase in government debt deterred private consumption in Nigeria.

Table 9: Variance Decomposition of Response of Government Debt

\begin{tabular}{lllllll}
\hline Period & S.E. & GEXP & TR & PC & B & IR \\
\hline 1 & 0.019234 & 2.258749 & 12.81888 & 8.602370 & 76.32000 & 0.000000 \\
2 & 0.027323 & 1.119267 & 6.360055 & 4.272048 & 87.84194 & 0.406691 \\
3 & 0.033852 & 1.486670 & 4.575711 & 3.044395 & 90.39388 & 0.499340 \\
4 & 0.038433 & 1.456325 & 3.631697 & 2.363880 & 91.87754 & 0.670558 \\
5 & 0.042037 & 1.963050 & 3.157141 & 2.028735 & 92.13075 & 0.720323 \\
6 & 0.044849 & 2.327449 & 3.436122 & 1.793452 & 91.69494 & 0.748035 \\
7 & 0.047177 & 2.900975 & 4.065909 & 1.638131 & 90.66855 & 0.726439 \\
8 & 0.049170 & 3.423743 & 5.290725 & 1.508867 & 89.08932 & 0.687342 \\
9 & 0.050945 & 4.016909 & 6.836295 & 1.406879 & 87.09841 & 0.641508 \\
10 & 0.052589 & 4.579016 & 8.751514 & 1.342282 & 84.72279 & 0.604400 \\
\hline
\end{tabular}

Note: Shocks are estimated using Factorization: Structural Standard Errors: Analytic

Standard errors are in parenthesis

Source: Author, 2015

Table 10: Variance Decomposition of Response of Tax Revenue

\begin{tabular}{lllllll}
\hline Period & S.E. & GEXP & TR & PC & B & IR \\
\hline 1 & 0.012079 & 6.774290 & 93.22571 & 0.000000 & 0.000000 & 0.000000 \\
2 & 0.016000 & 3.871441 & 80.79960 & 15.00261 & 0.023530 & 0.302824 \\
3 & 0.020790 & 3.148402 & 81.89483 & 14.06098 & 0.633807 & 0.261974 \\
4 & 0.024051 & 2.382366 & 80.39761 & 15.49161 & 1.244021 & 0.484391 \\
5 & 0.027017 & 2.053899 & 81.24575 & 13.97844 & 1.967759 & 0.754158 \\
6 & 0.029227 & 1.774554 & 81.55340 & 12.78575 & 2.608956 & 1.277342 \\
7 & 0.031164 & 1.597994 & 81.91831 & 11.40117 & 3.198061 & 1.884460 \\
8 & 0.032739 & 1.454068 & 81.90669 & 10.34459 & 3.711382 & 2.583263 \\
9 & 0.034125 & 1.343774 & 81.71952 & 9.540064 & 4.166493 & 3.230144 \\
10 & 0.035302 & 1.255853 & 81.38775 & 8.986464 & 4.573213 & 3.796718 \\
\hline
\end{tabular}

Note: Shocks are estimated using Factorization: Structural Standard Errors: Analytic

Standard errors are in parenthesis

Source: Author, 2015

The response of tax revenue to shocks in interest rates, government debt, government expenditure and private consumption was presented in the table 10. The response of tax revenue to shock in interest rate showed that 87 percent changed in interest rate responded to a change in tax revenue and 10.6 percent change in government debt also responded to change in tax revenue in the first period. In the third period, tax revenue responded to negative shocks from all the variables in the system. The negative shocks are $10.2 \%$, $17.6 \%$ and $5.8 \%$ from government debt, government expenditure and private consumption respectively. In addition, the response of tax revenue to shocks in both government expenditure and private consumption decreased as the periods increased until the ninth period and tenth period for government expenditure and private consumption respectively. Thus, this response indicated that the effect of fiscal policy shock on private consumption has non-Keynesian effect; this was in conformity with the work of Giavazzi and Pagano, (1996) and Giavazzi, Jappelli and Pagano, (2000). 
Table 11: Variance Decomposition of Response of Government Expenditure

\begin{tabular}{lllllll}
\hline Period & S.E. & GEXP & TR & PC & B & IR \\
\hline 1 & 0.021852 & 100.0000 & 0.000000 & 0.000000 & 0.000000 & 0.000000 \\
2 & 0.024483 & 93.39942 & 2.525189 & 1.759918 & 0.003548 & 2.311922 \\
3 & 0.028446 & 91.43210 & 2.348816 & 3.283824 & 0.067942 & 2.867318 \\
4 & 0.031167 & 85.97437 & 3.126064 & 7.357862 & 0.179891 & 3.361809 \\
5 & 0.033874 & 82.45655 & 3.076577 & 10.86279 & 0.411889 & 3.192197 \\
6 & 0.036269 & 78.25839 & 3.264394 & 14.87968 & 0.665353 & 2.932185 \\
7 & 0.038475 & 75.09137 & 3.287553 & 18.03089 & 0.948764 & 2.641424 \\
8 & 0.040454 & 72.17557 & 3.442434 & 20.77248 & 1.208420 & 2.401092 \\
9 & 0.042222 & 69.92746 & 3.608660 & 22.80984 & 1.446266 & 2.207771 \\
10 & 0.043799 & 68.02281 & 3.879517 & 24.39691 & 1.645818 & 2.054938 \\
\hline
\end{tabular}

Note: Shocks are estimated using Factorization: Structural Standard Errors: Analytic

Standard errors are in parenthesis

Source: Author, 2015

The response of government expenditure to shocks in government debt, tax revenue and private consumption as presented in table 8 showed that government expenditure responded to positive shocks in all the variables in the system but in different categories. The shock in government debt accounted for a maximum of $12.6 \%$ response to government expenditure. This showed that a unit percent shock in government debt would response to $12.6 \%$ changed in government expenditure. Shock in tax revenue accounted for approximately $30 \%$ changed in government expenditure. This showed that the Nigerian government financed larger part of her expenditure with the tax revenue generated either from oil or non-oil export. The shock in private consumption accounted for approximately $6 \%$ changed in government expenditure.

Table 12: Variance Decomposition of Response of Private Consumption

\begin{tabular}{lllllll}
\hline Period & S.E. & GEXP & TR & PC & B & IR \\
\hline 1 & 0.011995 & 11.24425 & 40.43348 & 48.32227 & 0.000000 & 0.000000 \\
2 & 0.012789 & 10.00800 & 35.76793 & 51.74420 & 0.829643 & 1.650232 \\
3 & 0.014439 & 9.069016 & 34.07171 & 54.00278 & 0.854806 & 2.001686 \\
4 & 0.014831 & 8.677438 & 33.15220 & 54.38960 & 1.035550 & 2.745212 \\
5 & 0.015294 & 8.220840 & 34.25510 & 53.70218 & 1.001781 & 2.820093 \\
6 & 0.015485 & 8.107072 & 35.15658 & 52.89592 & 0.980786 & 2.859642 \\
7 & 0.015725 & 7.874888 & 36.77847 & 51.59977 & 0.965988 & 2.780881 \\
8 & 0.015912 & 7.797348 & 38.05971 & 50.44187 & 0.984804 & 2.716263 \\
9 & 0.016119 & 7.669264 & 39.44033 & 49.19979 & 1.043357 & 2.647255 \\
10 & 0.016304 & 7.616353 & 40.55086 & 48.11917 & 1.125469 & 2.588152 \\
\hline
\end{tabular}

Note: Shocks are estimated using Factorization: Structural Standard Errors: Analytic

Standard errors are in parenthesis

Source: Author, 2015

The response of private consumption to shocks in government debt, tax revenue and government expenditure was presented in table 12. It showed that in the second period, the private consumption responded to negative shocks from all the variables in the system. Subsequently, government debt shock maintained a positive shocks for the rest of the periods likewise the tax revenue shock. This indicated that shocks from both government debt and tax revenue enhanced the change in private consumption positively. This was in conformity with the Keynesian effect of fiscal policy as indicated in the works of Schclarek, (2003) and; Medee and Nembee, (2011). However, private consumption responded to negative shock from government expenditure in the fourth period. This shock was more than $50 \%$, indicating that changed in government expenditure would result in decrease in private consumption. Hence, this was in conformity with the non-Keynesian effect of fiscal policy on private consumption (Giavazzi \& Pagano, 1996). Finally, at an average, private consumption responded to positive shocks in government debt, tax revenue and government spending. This showed a mixed results between Keynesian and non-Keynesian effect on private consumption in Nigeria. 
Impulse Response Function of Structural VAR Result: The impulse response function (IRF) enables one to analyze the response of one variable to a random shock in another variable while maintaining the original units of the data as well as providing an estimate of uncertainty. The results presented here were based on a Structural decomposition of the estimated residual covariance matrix of the estimated SVAR. Substantively, the IRF is useful because it provides a more statistically principle means of measuring a variable's response to changes in another variable. In the present context, the IRF helped in determining how quickly private consumption (fiscal policy variables) adjusted after being shocked by an unanticipated change in fiscal policy variables (private consumption). Such test provided support for substantive hypothesis test with respect to variable dynamics over time. If, for example, theory suggests that a change in fiscal policy variables should enhance private consumption over time, this expectation can be tested using the IRF. It is important to remember, however, that the results presented here were purely exploratory and were intended to assist with theoretical development by giving an account of the dynamic behaviour of fiscal policy variables and private consumption. Theory and evidence regarding the way an increase in government debts, government spending or a tax shock affect private consumption were not conclusive. In particular, neoclassical models predicted a negative response of this variable (Baxter \& King, 1993) while the opposite was found in Keynesian and neo-Keynesian models. On empirical grounds, Fatas and Mihov (2001), Blanchard and Perotti (2002) and Gali, Valles and Lopez-Salido (2007) found that the reaction of private consumption to an unexpected government spending shock was positive and persistent. On the contrary, Mountford and Uhlig (2009) found that the response of private consumption was statistically non-significant, while Ramey (2007) provided evidence of a negative reaction of private consumption. As for taxes, Romer and Romer (2007) found that tax increase had a large negative effect on private consumption.

The Effects of Shocks on Private Consumption: Figure 3 column 3 showed the impulse responses to one standard error shock to the private consumption equation at time $t$ on expected values of the endogenous variables in the SVAR at time $t+n$. In response to a shock to private consumption, government expenditure declined by $-0.03 \%$ at second quarter and this continued thereafter to $-0.08 \%$ at the end of the two years six months horizon. The response of government expenditure was larger on impact when compared to the response of taxes to innovations to private consumption. On the other hand, the response of taxes to private consumption declined by $-0.06 \%$ on impact but rose to a $-0.05 \%$ point increase in the fourth quarter. Taxes then rose in the eighth quarter by $0.001 \%$. Thereafter, taxes rose to $0.01 \%$ over the next two years. Thus, the impulse response of government spending and taxes to a shock to private consumption were both negative. This was in conformity with the result of Onodje (2009).

The Effects of Shocks on Government Expenditure: Under the assumption of perfect foresight, an unanticipated generalized one standard deviation innovation to government expenditure caused private consumption to rise to $0.04 \%$ in the first quarter which declined sharply to $-0.04 \%$ in the second quarter. In the third quarter, shocks in government expenditure resulted in $0.016 \%$ increase in private consumption. In the fourth quarter, private consumption declined to $0.004 \%$ and thereafter continued to remain unstable till the tenth quarter when private consumption declined to $-0.006 \%$. These findings indicated a mixed result. Hence, it lied between Keynesian and Neo-classical proposition. Thus, this was in conformity with nonKeynesian proposition and similar to the result of Alfonso and Sousa (2009). The shocks in government expenditure caused $0.03 \%$ increase in tax revenue in the first quarter and decrease in tax revenue by $0.001 \%$ in the second quarter. Hence, this continued to be unstable till eighth quarter and remained steady from the ninth quarter at zero percent till tenth quarter. Thus, the shocks on government expenditure crowded-out private consumption as argued in the Keynesian theory that increase in government expenditure would cause increase in private consumption through increase in income. This result was in conformity with the earlier studies (Onodje, 2009; Sousa, 2009; Mancellari, 2011). 
Figure 3: Responses to Structural One S.D. Innovations in Private Consumption to Shocks in Fiscal Policy Variables
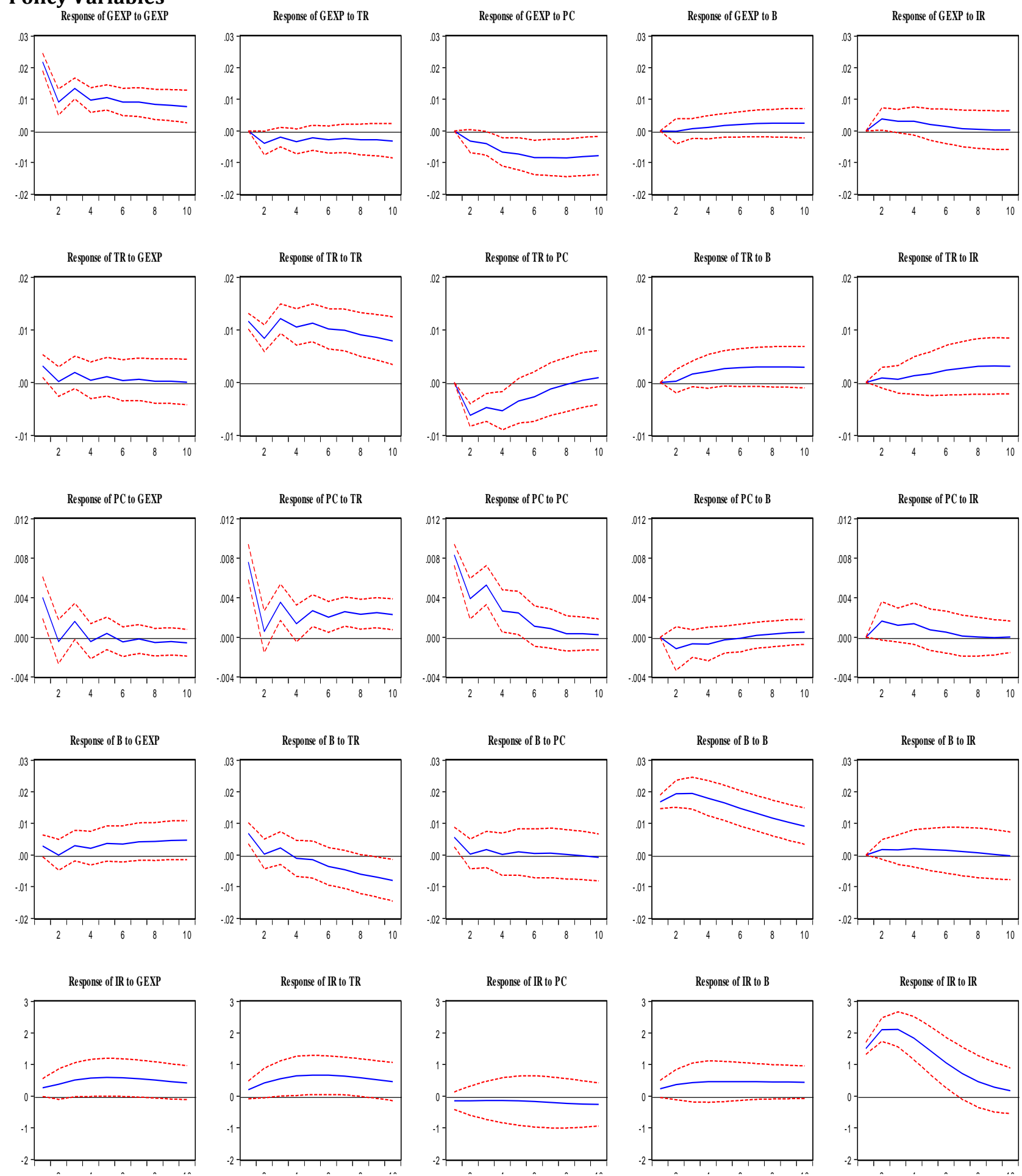

Source: Author, 2015

The Effects of Shocks on Tax Revenue: An unanticipated one standard deviation innovation to taxes caused private consumption to rise by $0.076 \%$ in the first quarter. The shock in taxes to private consumption declined to $0.006 \%$ in the second quarter. However, there was an unstable changed in the private consumption between third quarter and eighth quarter as a result of shocks in taxes. Meanwhile, in the tenth 
quarter the shock in taxes resulted to $0.023 \%$ stable in private consumption. Hence, these findings were against the Keynesian proposition that increase in tax revenue due to increase in tax rate would result to fiscal contraction. A positive shock to taxes had a significant negative effect on government spending since the one standard deviation bands included negative values for the entire horizon as shown in figure 5.3, column 2. This might be explained by a deficit-reducing tax increase behaviour that aimed at stabilizing or reducing government debt (Caldara \& Kampus, 2008). More specifically, the Nigerian government tends to raise taxes to ameliorate budget deficits and pay down debt incurred in previous periods (deficit-driven tax changes), rather than to raise taxes to increase public investment expenditure in future periods to enhance private consumption (spending-driven tax changes). Thus, a positive shock to taxes as a result of increase in government expenditure in the short-run resulted to an increase in government savings in other to reduce public debt accumulated in previous periods. In summary, figure 3 displayed the responses of private consumption to government debts, government spending and net-tax shocks. The responses of private consumption in the baseline SVAR notably decreased after a positive government spending shock, in line with non-Keynesian models, although such positive response phased out rather quickly. In the same vein, increase in net taxes brought private consumption upwards in quarters following the shocks and the response became significant after the fourth year. Also, the response of private consumption in the baseline SVAR showed an increasing response from a government debt shock in line with Keynesian models. This positive response did not phase out quickly.

Robustness Check of Structural VAR Results: The study employed various measures to test the stability and robustness of the SVAR results. First, in testing the stability condition of the model, the study employed $h$ the graphical root characteristic polynomial. The results of this technique indicated that all the roots of the characteristic polynomial were inside the unit circle signifying that the defined SVAR model was stable as shown in figure 4.

Figure 4: Stability Test Result Inverse Roots of AR Characteristic Polynomial

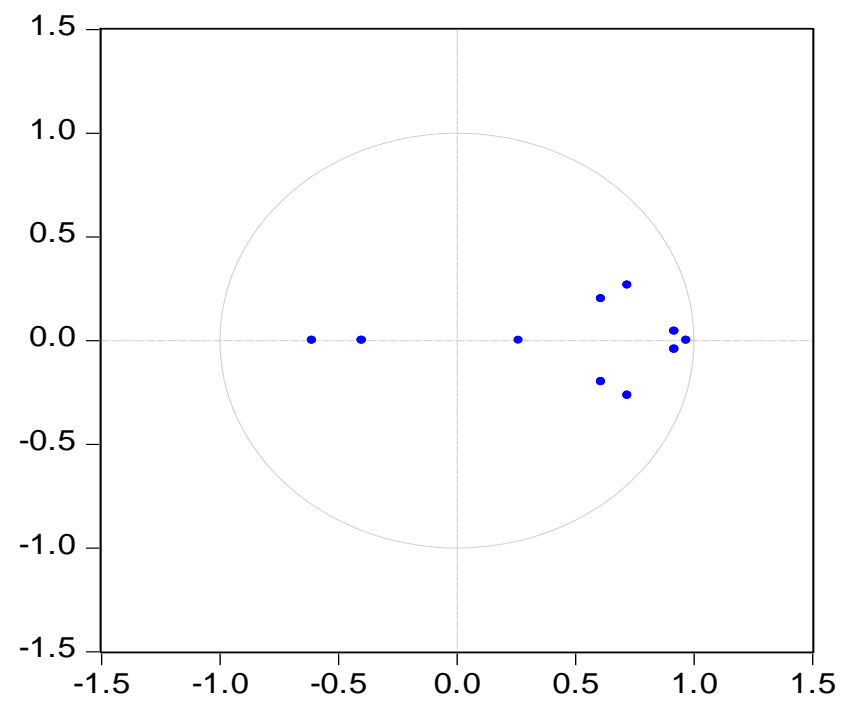

Source: Author, 2015

Furthermore, in addition to stability and robustness check the study estimated the matrices A and B to obtain the coefficients of structural shocks based on the earlier stated assumptions. The results of the short-run response pattern of the matrices A and B were presented in tables 13 and 14 respectively. 
Table 13: Estimated Coefficients of Matrices A and B using Blanchard-Perotti Method given that $\beta_{t r}^{g \exp }=0$ (Short-run Response Pattern)

$\hat{A}=\left[\begin{array}{ccccc}1 & 0 & 0 & 0.5 & 0 \\ 0 & 1 & -1.35 & -0.95 & 0 \\ 3.400 & 80.272 & 1 & 0 & 0 \\ -11.742 & 82.233 & -106.512 & 1 & 0 \\ -6.692 & -27.360 & 16.182 & -6.482 & 1\end{array}\right]$

$\hat{B}=\left[\begin{array}{ccccc}0 & 0.022 & 0 & 0 & 0 \\ 0.012 & 0.003 & 0 & 0 & 0 \\ 0 & 0 & 0.012 & 0 & 0 \\ 0 & 0 & 0 & 0.019 & 0 \\ 0 & 0 & 0 & 0 & 1.571\end{array}\right]$

Source: Author, 2015

(i) when $\beta_{t r}^{g \text { exp }}=0$, the coefficient of government expenditure shock was positively signed and statistically significant at $5 \%$ level. This finding indicated that a positive government shock would result to increase in private consumption by $2.2 \%$. This result was in conformity with the Keynesian proposition that stated that increase in government spending would result in increased private consumption through increase in disposable income. Also, the coefficient of tax revenue shock was positively signed and statistically significant at $5 \%$ level. The positive tax revenue shock showed that increase in tax revenue through increase in tax rate would result in $1.5 \%$ increase in private consumption. Thus, this result was in conformity with nonKeynesian proposition which stated that contractionary fiscal policy would have expansionary effect on macroeconomic variables.

Table 14: Estimated Coefficients of Matrices A and B using Blanchard-Perotti Method given that $\beta_{g \exp }^{t r}=0$ (Short-run Response Pattern)

$\hat{A}=\left[\begin{array}{ccccc}1 & 0 & 0 & 0.5 & 0 \\ 0 & 1 & -1.35 & -0.95 & 0 \\ 3.400 & 80.272 & 1 & 0 & 0 \\ -11.742 & 82.233 & -106.512 & 1 & 0 \\ -6.692 & -27.360 & 16.182 & -6.482 & 1\end{array}\right] \quad \hat{B}=\left[\begin{array}{ccccc}0.006 & 0.021 & 0 & 0 & 0 \\ 0.012 & 0 & 0 & 0 & 0 \\ 0 & 0 & 0.012 & 0 & 0 \\ 0 & 0 & 0 & 0.019 & 0 \\ 0 & 0 & 0 & 0 & 1.571\end{array}\right]$

Source: Author, 2015

(ii) when $\beta_{g \text { exp }}^{t r}=0$, a similar result was shown but their magnitudes vary. The coefficient of government spending shock was $2.7 \%$ while the coefficient of tax revenue shock was $1.2 \%$. Both coefficients were statistically significant at $5 \%$ level. The positive government spending shock was in conformity with Keynesian proposition while the positive tax revenue shock was in conformity with non-Keynesian proposition. In addition, the long-run response pattern of the SVAR result was equally presented as shown in table 15.

Table 15: Estimated Structural VAR Result for Long-run Response Pattern

$$
\hat{A}=\left[\begin{array}{ccccc}
1 & 0 & 0 & 0.5 & 0 \\
0 & 1 & -1.35 & -0.95 & 0 \\
-1.3218 & -0.7296 & 1 & 0 & 0 \\
1.1783 & -0.4587 & 0.5593 & 1 & 0 \\
1.4915 & -3.5937 & 4.1248 & 2.2652 & 1
\end{array}\right] \quad\left[\begin{array}{c}
\hat{e}_{t}^{g \exp } \\
\hat{e}_{t}^{t r} \\
\hat{e}_{t}^{p c} \\
\hat{e}_{t}^{b} \\
\hat{e}_{t}^{i r}
\end{array}\right]=\left[\begin{array}{c}
1.1605 \\
-1.8942 \\
-1.8023 \\
0.0397 \\
14.0527
\end{array}\right]
$$

Source: Author, 2015 
The long-run response pattern of the SVAR result showed that the coefficient of government spending shock was positive while the coefficient of tax revenue shock was negative. The positive government expenditure shock indicated that a unit unexpected increase in government spending would result to 1.2 un expected increase in private consumption. This was however similar to short-run response pattern. Hence, it was in conformity with the Keynesian proposition. At a final note, a negative tax revenue shock showed that a unit unexpected increase in tax rate would lead to 1.9 unexpected decrease in private consumption. This result was in conformity with the Keynesian proposition that stated that a contractionary fiscal policy in term of increase in tax rate would lead to decrease in consumer's income and this would result to decrease in private consumption in the long-run. This result was in conformity with the earlier studies by Onodje (2009) and Sousa (2009).

\section{Conclusion and Recommendations}

The paper concluded that a shock in government spending hit private consumption negatively while a positive shock in tax revenue contributed to a change in private consumption. This showed that a unit positive shock in government revenue reduced private consumption by 97 percent and this crowded-in private consumption in Nigeria. Also, the negative shock emanated from government expenditure to government debt indicated that discretionary government policy in terms of change in government expenditure reacted inversely to change in government debt. The response of tax revenue to shocks in both government expenditure and private consumption decreased, indicating that the effect of fiscal policy shock on private consumption has non-Keynesian effect in Nigeria. Furthermore, the private consumption responded to positive shocks in government debt, tax revenue and government spending. This showed a mixed results between Keynesian and non-Keynesian effect on private consumption in Nigeria and the response of private consumption in the baseline SVAR showed an increasing response from a government debt shock in line with Keynesian models. Hence, the results of the paper confirmed the existence of both the Keynesian and non-Keynesian effect of fiscal policy. In line with this, this paper recommended that government should exercise fiscal discipline; this can be achieved through reduction of wasteful spending. With this step, it will be relatively easy to determine the expenditure growth pattern in Nigeria.

Acknowledgement: I am grateful to the University of South Africa (UNISA) for giving me an opportunity to showcase my research talent as a Postdoctoral fellow in the Department of Economics, College of Economics and Management Sciences, UNISA as well as sponsoring my research output and my Mentor- Prof CJ Van Aardt for his endless guidance.

\section{References}

Abderrahim, F., Sha-Abdul, W. \& Parrel, A. (2010). Macroeconomic Effects of Fiscal Policy Shocks in Algeria: An Empirical Study. Working Paper Series. No. 536.

Alfonso, A. \& Sousa, R. M. (2009). The Macroeconomic Effects of Fiscal Policy in $\quad$ Portugal: $\quad$ a $\quad$ Bayesian SVAR Analysis. NIPE WP3/2009. Universidad do Minho.

Alfred, A. H., Tomasz J. \& Anna S. (2013). Combining Monetary and Fiscal Policy in an SVAR for a Small Open Economy. NBP Working Paper No. 168

Blanchard, O. \& Perotti, R. (2002). An Empirical Characterization of the Dynamic Effects $\quad$ of Changes in Government Spending and Taxes on Output. The Quarterly Journal of Economics, 117, 1329-68.

Brandt, P. T. \& Williams, J. T. (2007). New Introduction to Multiple Time Series Analysis. Springer.

Braun, P. A. \& Mittnik, S. (1993). Misspecifications in Vector Auto regression and Their Effects on Impulse Responses and Variance Decompositions. Journal of Econometrics [online], 59(3), 319 - 341.

Burriel, P., de Castro, F., Garrote, D., Gordo, E., Paredes, J. \& Pérez, J. J. (2009). Fiscal Policy Shocks in the Euro Area and the Us: An Empirical Assessment, European Central Bank, Working Paper Series No 1133.

Caldara, D. \& Kamps. C. (2008). What are the Effects of Fiscal Policy Shocks? A VAR-Based Comparative Analysis, ECB Working Paper Series No 877.

Cavallo, M. (2005). Government Employment Expenditure and the Effects of Fiscal Policy Shocks, Federal Reserve Bank of San Francisco. Working Paper Series 2005-16

CBN (Central Bank of Nigeria). (2014). Annual Report. Abuja: Central Bank of Nigeria.

Den-Haan, W. J. \& Georg, K. (2006). Anticipated Growth and Business Cycles in Matching Models, manuscript, University of Amsterdam. 
Engle, R. F. \& Granger, C. W. J. (1987). Co-integration and Error Correction Representation, Estimation and Testing. Econometrica, 55, 251-276.

Fatas, A. \& Mihov, I. (2001). The Effects of Fiscal Policy on Consumption and Employment: Theory and Evidence. CEPR Discussion Paper, No. 2760.

Favero, C., Giavazzi, A. \& Francesco, C. (2007). Debt and the effects of fiscal policy, Working paper series // Federal Reserve Bank of Boston, No. 07-4.

Galí, J., Vallés, J. \& López-Salido, J. D. (2007). Understanding the effects of government spending on consumption. Journal of the European Economic Association, 5, 227-270.

Giavazzi, F. \& Pagano, M. (1996). Non-Keynesian Effects of Fiscal Policy Changes: International evidence and the Swedish Experience. Swedish Economic Policy Review, 3, 67-103.

Giavazzi, F., Jappelli, T. \& Pagano, M. (2000). Searching for non-linear effects of fiscal policy: evidence from industrial and developing countries. European Economic Review, 44(7), 1259-1289.

Hamilton, J. D. (1994). Time Series Analysis, Princeton University Press, Princeton, New Jersey.

Heppke-Falk, K. H., Tenhofen, J. \& Wolf, G. B., (2006). The Macroeconomic Effects of Exogenous Fiscal Policy Shocks in Germany: a Disaggregated SVAR Analysis [online]. Deutsche Bundesbank Discussion Paper Series 1: Economic Studies, No 41

House, C. L. \& Shapiro M. D. (2006). Phased-In Tax Cuts and Economic Activity. American Economic Review, 96(4), 1835-1849.

Kumar, M., Daniel, L. \& Alexander, P. (2007). Fiscal Adjustments: Determinants and Macroeconomic consequences, IMF Working Paper 07/178.

Lozano, I. \& Rodriquez, K. (2008). Assessing the Macroeconomic Effects of Fiscal Policy in Colombia [online]. Banco de la Republica, Borradores de Economia Working Paper, No. 552.

Mançellari, A. (2011). Macroeconomic effects of Fiscal Policy in Albania: A SVAR Approach. Bank of Albania, Albania. No. 657.

Medee, P. N. \& Nenbee, S. G. (2011). Econometric Analysis of the Impact of Fiscal Policy Variables on Nigeria's Economic Growth (1970-2009). International Journal of Economic Development Research and Investment, 2(1).

Mountford, A. \& Uhlig, H. (2009). What are the effects of fiscal policy shocks? Journal of Applied Econometrics, 24(6), 960-992.

Nazir, R., Anwar M., Irshad M. \& Shoukat A. (2013). Does Fiscal Policy Matter for Growth? Empirical Evidence from Pakistan. International Journal of Economics and Finance, 5(3).

Onodje, M. A. (2009). An Insight into the Behavior of Nigeria's Private Consumer Spending. African Journal of Business Management, 3(9), 383-389.

Orisadare, M. A. (2012). The Effect of Fiscal Policy Shocks on Economic Activities in Nigeria: (1970-2009), Department of Economics, Faculty of Social Sciences, Obafemi Awolowo University, Ile-Ife. Unpublished Ph.D Thesis.

Perotti, R. (2004). Estimating the effects of fiscal policy in OECD Countries. IGIER- University Bocconi and Centre for Economic Policy, 2, 1-43.

Perroti, R. (2008). In search of the Transmission Mechanism of Fiscal Policy. NBER Macroeconomics. University of Chicago Press, 22, 169-226.

Ramey, V. A. (2011). Identifying Government Spending Shocks: It's all in the Timing. Quarterly Journal of Economics, 126(1), 1-50.

Ravnik, R. \& Zilic, I. (2011). The Use of SVAR Analysis in Determining the Effects of Fiscal Shocks in Croatia. Financial Theory and Practice, 35(1), 37-67.

Romer, C. \& Romer, D. (2007). The Macroeconomic Effects of Tax Changes: Estimates Based on a New Measure of Fiscal Shocks. NBER Working Paper 13264.

Schclarek, A. (2003). Fiscal policy and private consumption in industrial and developing countries. Department of Economics, Lund University, Working Papers No. 2003:20.

Shaheen, R. \& Turner, P. (2009). Measuring the dynamic Effects of Fiscal Policy shocks in Pakistan. Laugh borough University, UK.

Sousa, R. M. (2009). The Impact of Government Spending on the Private Sector: Crowding-Out versus Crowding-In Effects, University of Minho, NIPE Working Paper No. 6.

Yang, L. \& Shu-Chun S. (2005). Quantifying Tax Effects under Policy Foresight. Journal of Monetary Economics, 52(8), 1557-1168. 